\title{
Highly efficient mixed-metal spinel cobaltite electrocatalysts for the oxygen evolution reaction
}

\author{
Leiming Tao a,b, Penghu Guo a, Weiling Zhu a, Tianle Li a, Xiantai Zhou d, Yongqing Fu c, \\ Changlin $\mathrm{Yu}$ a, \#, Hongbing Ji a,d, * \\ a School of Science, Guangdong University of Petrochemical Technology, Maoming 525000, Guangdong, China \\ b Wuhan National Laboratory for Optoelectronics, Huazhong University of Science and Technology, Wuhan 430074, Hubei, China \\ c Faculty of Engineering and Environment, Northumbria University, Newcastle upon Tyne, NE1 8ST, UK \\ d Fine Chemical Industry Research Institute, School of Chemistry, Sun Yat-sen University, Guangzhou 510275, Guangdong, China
}

\section{A R T I C L E I N F O}

\section{Article history:}

Received 11 March 2020

Accepted 14 April 2020

Published 5 December 2020

\section{Keywords:}

Cation-substituted spinel cobaltites

Crystal field

Oxygen evolution reaction

Water-splitting

Electrocatalysis

\begin{abstract}
A B S T R A C T
Cation substitution in spinel cobaltites (e.g., $\mathrm{ACO}_{2} \mathrm{O}_{4}$, in which $\mathrm{A}=\mathrm{Mn}, \mathrm{Fe}, \mathrm{Co}, \mathrm{Ni}, \mathrm{Cu}$, or $\mathrm{Zn}$ ) is a promising strategy to precisely modulate their electronic structure/properties and thus improve the corresponding electrochemical performance for water splitting. However, the fundamental principles and mechanisms are not fully understood. This research aims to systematically investigate the effects of cation substitution in spinel cobaltites derived from mixed-metal-organic frameworks on the oxygen evolution reaction (OER). Among the obtained $\mathrm{ACo}_{2} \mathrm{O}_{4}$ catalysts, $\mathrm{FeCo}_{2} \mathrm{O}_{4}$ showed excellent OER performance with a current density of $10 \mathrm{~mA} \cdot \mathrm{cm}^{-2}$ at an overpotential of 164 $\mathrm{mV}$ in alkaline media. Both theoretical calculations and experimental results demonstrate that the Fe substitution in the crystal lattice of $\mathrm{ACo}_{2} \mathrm{O}_{4}$ can significantly accelerate charge transfer, thereby achieving enhanced electrochemical properties. The crystal field of spinel $\mathrm{ACo}_{2} \mathrm{O}_{4}$, which determines the valence states of cations A, is identified as the key factor to dictate the OER performance of these spinel cobaltites.
\end{abstract}

(C) 2020, Dalian Institute of Chemical Physics, Chinese Academy of Sciences. Published by Elsevier B.V. All rights reserved.

\section{Introduction}

Solar or wind energy can be converted from electricity into chemical energy, and hydrogen fuel can be generated and stored by means of water splitting. During water splitting, the reaction kinetics of the oxygen evolution reaction (OER) at the anode are typically much slower than those of the hydrogen evolution reaction at the cathode. [1]. Therefore, it is critical to accelerate the rate of the OER at the anode and improve the overall efficiency of water-splitting. Currently, iridium dioxide

\footnotetext{
* Corresponding author. Tel/Fax: +86-668-2923081; E-mail: jihb@mail.sysu.edu.cn

\# Corresponding author. E-mail: yuchanglinjx@163.com

This work was supported by the National Natural Science Foundation of China (21938001, 21576302, 21878344, 21961160741), Natural Science Foundation of China-SINOPEC Joint Fund (U1663220), Featured Innovation Project of Guangdong Education Department (2018KTSCX144, 2016KTSCX087), Guangdong Provincial Key R\&D Programme (2019B110206002), the Local Innovative and Research Teams Project of Guangdong Pearl River Talents Program (2017BT01C102), Scientific Research Fund of Natural Science Foundation of Guangdong University of Petrochemical Technology (2019rc019, 2019rc053), Guangdong Province Universities and Colleges Pearl River Scholar Funded Scheme (2019), Key Natural Science Research Projects of Guangdong Provincial Universities (2019KZDXM010), Guangdong Basic and Applied Basic Research Foundation (2019A1515011249), the UK Engineering and Physical Sciences Research Council (EPSRC) for support under grant EP/P018998/1, and Newton Mobility Grant (IE161019) through the Royal Society and the National Natural Science Foundation of China. DOI: 10.1016/S1872-2067(20)63638-5 | http://www.sciencedirect.com/science/journal/18722067 | Chin. J. Catal., Vol. 41, No. 12, December 2020
} 
$\left(\mathrm{IrO}_{2}\right)$ and ruthenium dioxide $\left(\mathrm{RuO}_{2}\right)$ have been commonly used as OER catalysts. However, the most frequently used electrocatalysts, $\mathrm{IrO}_{2}$ and $\mathrm{RuO}_{2}$, are not only expensive but also have unsustainable supply and environmental issues. Hence, it is critical to develop non-noble and abundant metal-based electrocatalysts for the OER, with good catalytic activity and high durability for practical applications in water splitting. To date, huge efforts have been made to develop transition metal oxides/hydroxides [2], phosphate [3], and sulfides [4] for the OER.

Three-dimensional metal-based spinel oxides have recently attracted enormous attention due to the wide range of technological applications in the semiconductor industry, such as high-frequency devices, catalysts, magnetic recordings, biomedical devices, microwave absorbers, gas sensors, and optical materials/devices [5-8]. They possess a stoichiometric $\mathrm{AB}_{2} \mathrm{O}_{4}$ cubic structure, where A and B stand for tetrahedral and octahedral configurations of transition metals, respectively [9]. Because of highly distributed metal cations A and B between each position with different oxidation states in the spinel structure $\mathrm{AB}_{2} \mathrm{O}_{4}$, the mixed-transition metal spinel structures exhibit various interesting physical and chemical properties, particularly in the catalytic field. The partially filled nature of the $3 d$ transition metal orbitals enables the electron transfer process, which plays a key role in creating excellent magnetic, electronic, and electrochemical properties. These provide us with an opportunity to tune their electrical structures at the atomic scale to achieve highly efficient water splitting electrocatalysts and further match the demand for electrolyzers and fuel cells, etc. [10]. Recently, there has been an increased interest in using mixed-metal spinel oxides for the OER applications [11-14].

However, the relationship between the electrocatalytic performance of the mixed-metal spinel oxides and their elementary compositions, valence states, and distribution of sites is still not fully understood. Experimental observations and theoretical analyses have been performed [15-18] to identify the exact roles of spinel oxides in the OER. For example, Prabu et al. [19] found that $\mathrm{Ni}^{3+}$ ion substitution at the octahedral sites of the $\mathrm{NiCo}_{2} \mathrm{O}_{4}$ can significantly enhance the OER performance. Hutchings et al. [20] reported that the active sites of $\mathrm{Co}_{3} \mathrm{O}_{4}$ for the OER are mainly the octahedral sites of $\mathrm{Co}^{3+}$. Wei et al. [17] identified that $\mathrm{Mn}^{3+}$ ions in the octahedral positions of $\mathrm{MnCo}_{2} \mathrm{O}_{4}$ are the active sites for the OER. These well-documented studies clearly indicate that electrocatalytic performances of the cobalt-based spinel oxides for the OER strongly depend on the valence states of transition metal cations (A) and their corresponding site distributions in the $\mathrm{ACo}_{2} \mathrm{O}_{4}$ spinel structure [10]. The substitution of transition metal cations (A) can be a promising strategy for precisely modulating the electronic properties and optimizing the electrochemical OER performance of cobalt-based spinel oxides (e.g., $\mathrm{ACo}_{2} \mathrm{O}_{4}$, in which $\mathrm{A}=\mathrm{Mn}, \mathrm{Fe}$, $\mathrm{Co}, \mathrm{Ni}, \mathrm{Cu}$, or $\mathrm{Zn}$ ).

In this paper, we report a series of the cobalt-based spinel oxides with well-defined compositions and morphologies, derived from the precursor mixed-metal-organic frameworks (MMOFs). A site substitution by different transition metal cati- ons in cobalt-based spinel oxides and their corresponding OER behavior have been discussed in detail. Among these $\mathrm{ACo}_{2} \mathrm{O}_{4}$, $\mathrm{FeCo}_{2} \mathrm{O}_{4}$ showed an excellent catalytic activity with a current density of $10 \mathrm{~mA} \cdot \mathrm{cm}^{-2}$ at an overpotential of $164 \mathrm{mV}$ in alkaline media. Furthermore, charge transport, electronic structure, and spinel crystal fields of these $\mathrm{ACo}_{2} \mathrm{O}_{4}$ were systematically investigated based on experimental studies and density functional theory (DFT) calculations. The underlying mechanisms for the enhanced electrocatalytic performance induced by substitutions of cations with different numbers of $d$-electrons between 5 and 10 have also been clarified.

\section{Experimental}

\subsection{Synthesis of FeCo2-PTCDA MMOFs.}

In a typical synthesis process [21], $\mathrm{Fe}(\mathrm{OAc})_{2} \cdot 2 \mathrm{H}_{2} \mathrm{O}(0.133$ mmol) and $\mathrm{Co}(\mathrm{OAc})_{3} \cdot 4 \mathrm{H}_{2} \mathrm{O}(0.267 \mathrm{mmol})$ were dissolved in $22.5 \mathrm{~mL}$ deionized water, and PTCDA ( $0.2 \mathrm{mmol})$ was dissolved in $12.5 \mathrm{~mL} \mathrm{NaOH}$ solution ( $0.8 \mathrm{mmol} \mathrm{NaOH})$. The PTCDA solution was added dropwise to the mixed solution of metal acetates under constant stirring. The immediate formation of a precipitate was observed. The reaction mixture was stirred at room temperature for $30 \mathrm{~min}$, and then transferred into a Teflon-lined stainless steel vessel $(45 \mathrm{~mL})$ and heated at $100{ }^{\circ} \mathrm{C}$ for $8 \mathrm{~h}$. After cooling down to room temperature, the precipitate was collected by centrifugation, washed with water and dried.

The obtained $\mathrm{FeCo}_{2}-\mathrm{PTCDA}$ MOFs were annealed at $400{ }^{\circ} \mathrm{C}$ in the air for $1 \mathrm{~h}$ with a heating ramp of $1^{\circ} \mathrm{C} \cdot \mathrm{min}^{-1}$. For the synthesis of other ACo2-PTCDA ( $=\mathrm{Zn}, \mathrm{Cu}, \mathrm{Ni}, \mathrm{Co}$, and $\mathrm{Mn}$ ) MMOFs, the processes are similar to those described above for the FeCo2-PTCDA, except for the choice of metal acetates.

\subsection{Catalyst characterization}

Morphologies, chemical compositions, and crystalline structures of all the samples were characterized using various methods. The X-ray diffraction (XRD) measurements were performed using an X'pert PRO diffractometer (PANalytical B.V.) with a $\mathrm{Cu} K_{\alpha} \mathrm{X}$-ray source operated at $40 \mathrm{kV}$ and $40 \mathrm{~mA}$. Surface and internal microstructures were investigated using field emission scanning electron microscopy (FE-SEM, Nova NanoSEM 450) and high-resolution transmission electron microscopy (HR-TEM, 300 kV Titan Probe corrected TEM, Titan G2 60-300). Surface chemical states of the samples were analyzed using an X-ray photoelectron spectroscopy (XPS, Thermofisher-ESCALab 250). The shift of the core-level spectra was calibrated using the $\mathrm{C} 1 s$ neutral carbon peak at $284.8 \mathrm{eV}$. The Brunauer-Emmett-Teller (BET) surface area $\left(S_{\mathrm{BET}}\right)$ and pore size distribution were determined using a Micromeritics ASAP 2000 nitrogen adsorption apparatus. All the samples were degassed at $180^{\circ} \mathrm{C}$ prior to the BET measurements.

\subsection{Electrochemical measurements}

The catalytic activity of the prepared $\mathrm{ACo}_{2} \mathrm{O}_{4}$ loaded onto standard glassy carbon electrodes was evaluated using elec- 
trochemical measurements for the OER with a three-electrode electrochemical cell in $1 \mathrm{M} \mathrm{KOH}$ aqueous solution as the elec-

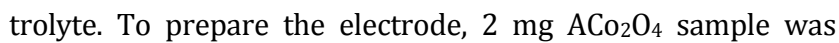
dispersed into a $1 \mathrm{~mL}$ mixture of water, ethanol, and Nafion solution (5 wt\% in a mixture of lower aliphatic alcohols and water, Aldrich) with a volume ratio of 1:3.85:0.15, under a constant ultra-sonication for $10 \mathrm{~min}$. The final catalyst ink suspension had a concentration $2.0 \mathrm{mg} \cdot \mathrm{mL}^{-1}$, and its suspension of $19.8 \mu \mathrm{L}$ was then transferred onto a polished glassy-carbon electrode of $5 \mathrm{~mm}$ in diameter, resulting in a mass loading of $0.2 \mathrm{mg} \cdot \mathrm{cm}^{-2}$.

Cyclic voltammetry (CV) and linear sweep voltammetry (LSV) were conducted using an electrochemical station (CHI 750D, CH Instruments). Standard glassy carbon (GC) electrode ( $5 \mathrm{~mm}$ in diameter, Pine Instruments) was used as the working electrode. $\mathrm{Hg} / \mathrm{HgO}$ was used as the reference electrode, and a graphite electrode was used as the counter electrode. Tafel plots of the samples were obtained similar to those reported in the literature [22,23]. LSV curves and Tafel plots were recorded at two different scan rates of 5 and $0.1 \mathrm{mV} \cdot \mathrm{s}^{-1}$, respectively. Electrochemical impedance spectroscopy (EIS) was used (Autolab PGSTAT302N) with a frequency range from $0.01 \mathrm{~Hz}$ to 1 $\mathrm{MHz}$ and a potential amplitude of $10 \mathrm{mV}$. Impedance value (R) of the $1 \mathrm{M} \mathrm{KOH}$ solution was measured to be $6.9 \Omega$ at room temperature. Unless stated otherwise, the tests were made without iR compensation in $1 \mathrm{M} \mathrm{KOH}$ solution.

Measurements using rotating ring-disk electrodes (RRDEs) were conducted in $1 \mathrm{M} \mathrm{KOH}$ electrolyte at room temperature using a three-electrode system (Pine Instruments and WaveDriver Workstation). The measurement was conducted in a solution of $\mathrm{N}_{2}$-saturated $1 \mathrm{M} \mathrm{KOH}$ for seven times with various rotation speeds (i.e., 400, 620, 900, 1225, 1600, 2025, 2500 rpm). The Tafel slope was calculated using the Koutecký-Levich equation with the RRDE for the OER without $i R$ [24]:

$$
\frac{1}{i}=\frac{1}{i_{\mathrm{K}}}+\frac{1}{i_{\mathrm{L}}}=\frac{1}{i_{\mathrm{K}}}+\frac{1}{0.62 \mathrm{nFAD} \mathrm{O}^{2 / 3} \omega^{1 / 2} v^{-1 / 6} \mathrm{C}_{0}^{*}}
$$

The electrochemical surface area (ECSA) of the catalyst plays a crucial role in electrochemical reactions. To study the ECSA of $\mathrm{ACo}_{2} \mathrm{O}_{4}$, we conducted cyclic voltammograms at different scan rates $(10,20,30,40,50,60,70,80,90,100,110$, and $120 \mathrm{mV} \cdot \mathrm{s}^{-1}$ ) in a non-faradaic potential region. The ECSA is the product of $\mathrm{R}_{\mathrm{F}} \mathrm{S}$, in which $\mathrm{R}_{\mathrm{F}}$ stands for the roughness factor, which is obtained from the ratio of $C_{\mathrm{dl}}$ of the test sample and the $C_{s}\left(=60 \mu \mathrm{F} \cdot \mathrm{cm}^{-2}\right)$ of a smooth surface [25]. S stands for the real surface area of the smooth metal electrode, which generally equals the geometric area of the carbon electrode [26]. The values of $C_{\mathrm{dl}}$ were obtained using cyclic voltammetry, and the results are shown in Fig. S3. As shown in Fig. S3, the $C_{\text {dl }}$ were obtained to be 8, 5.4, 5.3, 3.7, 2.6 and $1 \mathrm{mF} \cdot \mathrm{cm}^{2}$ for $\mathrm{ZnCo}_{2} \mathrm{O}_{4}$, $\mathrm{Co}_{3} \mathrm{O}_{4}, \mathrm{NiCo}_{2} \mathrm{O}_{4}, \mathrm{MnCo}_{2} \mathrm{O}_{4}, \mathrm{FeCo}_{2} \mathrm{O}_{4}$, and $\mathrm{CuCo}_{2} \mathrm{O}_{4}$, respectively.

The faradaic efficiency (FE) was obtained according to the method reported in the literature [27]. The FE (or current efficiency) is defined as the ratio of the measured amount of produced oxygen and the theoretical amount of produced oxygen, according to Faraday's Law. It can be calculated as follows:

$$
\eta=4(N \times F) /(I \times t)
$$

where $\eta$ is the theoretical yield (current efficiency); $N$ stands for the Molar amount of produced oxygen; I represents the current in ampères; $\mathrm{t}$ is the time in seconds (in this work, $t=1$ $\min$ ); 4 is the oxidation state (number of displaceable electrons per $\mathrm{O}_{2}$ ); and $F$ is Faraday's constant, $F=96487 \mathrm{C} \cdot \mathrm{mol}^{-1}$.

Chronopotentiometry was applied at a given potential (1.53 V) to maintain constant $\mathrm{O}_{2}$ generation. $\mathrm{N}_{2}$ was constantly purged into the cathodic compartment at a flow rate of 5 $\mathrm{cm}^{3} \cdot \mathrm{min}^{-1}$, and the compartment was connected to the gas-sampling loop of a gas chromatograph (GC2020, Hubei Hengxinshiji Scientific Instrument Co.). A thermal conductivity detector (TCD) was used to detect and quantify the generated $\mathrm{O}_{2}$.

All the measured potentials were calibrated using a reversible hydrogen electrode (RHE) based on the following equation:

$$
E_{\mathrm{RHE}}=E_{\mathrm{Hg} / \mathrm{HgO}}+0.098 \mathrm{~V}+0.059 \mathrm{pH}
$$

\subsection{Density functional theory calculations}

All the DFT calculations were performed using the Vienna $\mathrm{Ab}$ initio Simulation Package (VASP) [28]. The interaction between core ions and valence electrons was described by the projector augmented wave (PAW) method [29], while the generalized gradient approximation (GGA) with the Perdew-Burke-Ernzerhof (PBE) function was used for electron exchange-correlation interactions [30]. The energy cut-off for the plane waves was chosen to be $520 \mathrm{eV}$. To correctly describe the electronic structure of the A-3d states $(A=M n, F e, C o, N i$, $\mathrm{Cu}$, and $\mathrm{Zn}$ ), a rotational invariant type GGA+U method, as proposed by Dudarev et al. [31], was employed. The effective onsite Coulomb terms (U values) for the $3 \mathrm{~d}$ states of $\mathrm{Mn}, \mathrm{Fe}, \mathrm{Co}$, $\mathrm{Ni}, \mathrm{Cu}$, and $\mathrm{Zn}$ were selected to be $5.5,3,4.5,10.5,4.5$, and 10 $\mathrm{eV}$, respectively. The Monkhorst-Pack scheme sampling with a $2 \times 2 \times 2$ k-point mesh was adopted for the integration in the irreducible Brillouin zone. The structural parameters of the $\mathrm{ACo}_{2} \mathrm{O}_{4}$ were obtained based on the XRD analysis. The lattice parameters and atomic positions were fully relaxed and calculated using the hybrid HSE06 functional, and the final forces on the relaxed atoms were less than $0.05 \mathrm{eV} \cdot \mathrm{A}^{-1}$. Spin-polarized calculations and ferromagnetic ordering were employed for all the cases.

\section{Results and discussion}

To identify the exact role of spinel oxides (Figs. S1 and S2), the $\mathrm{ACo}_{2} \mathrm{O}_{4}$ with well-defined morphologies and compositions was synthesized under a controlled temperature as low as 350 ${ }^{\circ} \mathrm{C}$ [21]. The OER activities of $\mathrm{ACo}_{2} \mathrm{O}_{4}$ samples were investigated using a standard three-electrode configuration with $1 \mathrm{M} \mathrm{KOH}$ aqueous solution at $25{ }^{\circ} \mathrm{C}$. Figs. $1(\mathrm{a})$ and 1(b) show the OER specific activities of $\mathrm{ZnCo}_{2} \mathrm{O}_{4}$ (curve 1), $\mathrm{CuCo}_{2} \mathrm{O}_{4}$ (curve 2), Ni$\mathrm{Co}_{2} \mathrm{O}_{4}$ (curve 3), $\mathrm{Co}_{3} \mathrm{O}_{4}$ (curve 4), $\mathrm{FeCO}_{2} \mathrm{O}_{4}$ (curve 5), and $\mathrm{MnCo}_{2} \mathrm{O}_{4}$ (curve 6) at a scan rate of $5 \mathrm{mV} \cdot \mathrm{s}^{-1}$ after correction by removing the contribution of ECSA (Fig. S3). We compared the Tafel plots and overpotentials at $10 \mathrm{~mA} \cdot \mathrm{cm}^{-2}$ using various OER catalysts (Fig. 1(c)). The catalytic dynamics in terms of the turnover frequency (TOF) were further analyzed for $\mathrm{ACo}_{2} \mathrm{O}_{4}$ 
a)

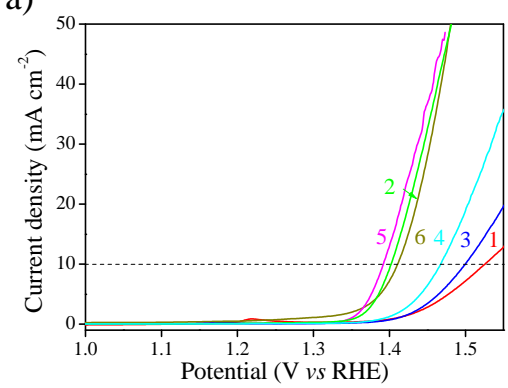

d)

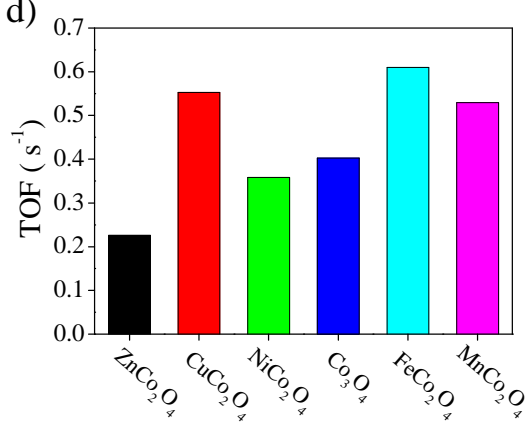

b)

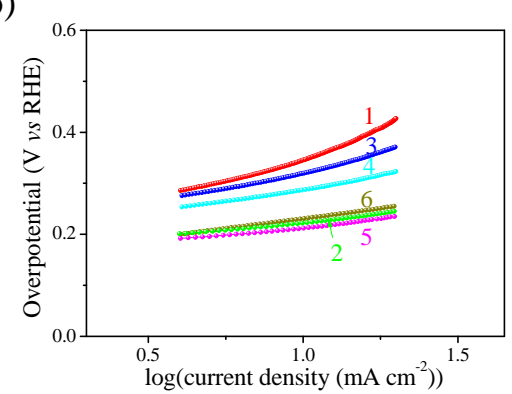

e)

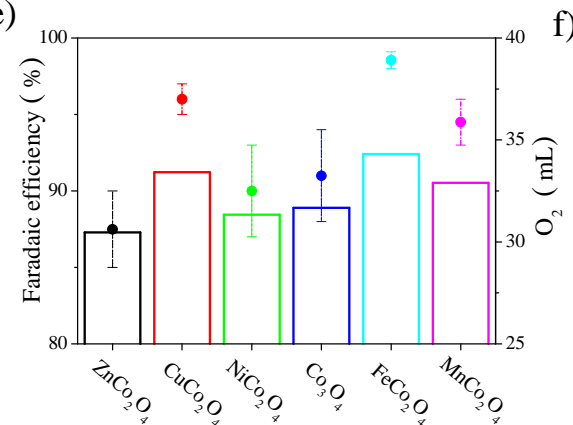

C)

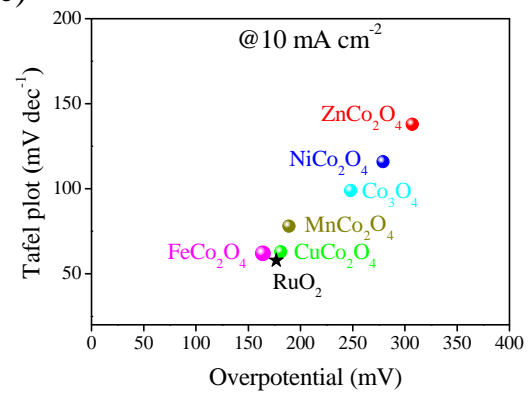

f)

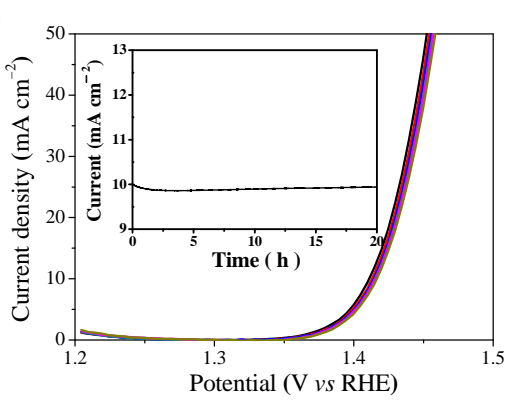

Fig. 1. Electrochemical measurements: (a) linear sweep polarization curves (LSV) of $\mathrm{ZnCo}_{2} \mathrm{O}_{4}$ (1), $\mathrm{CuCo}_{2} \mathrm{O}_{4}(2), \mathrm{NiCo}_{2} \mathrm{O}_{4}(3), \mathrm{Co}_{3} \mathrm{O}_{4}(4), \mathrm{FeCo}_{2} \mathrm{O}_{4}$ (5), and $\mathrm{MnCo}_{2} \mathrm{O}_{4}$ (6) for the OER specific activities (corrected by removing the contribution of ECSA) in $1 \mathrm{M} \mathrm{KOH}$; (b) Tafel slopes; (c) Tafel slope versus overpotential at $10 \mathrm{~mA} \cdot \mathrm{cm}^{-2}$ for reported OER catalysts; (d) Turnover frequency (TOF) of specific activity for $\mathrm{ACo}_{2} \mathrm{O}_{4}$; (e) FE for the OER, and the average oxygen production of $\mathrm{ACO}_{2} \mathrm{O}_{4}$; (f) Chronoamperometric response recorded using $\mathrm{FeCo}_{2} \mathrm{O}_{4}$, initially and after 10000 cycles with a scan rate of 100 $\mathrm{mV} \cdot \mathrm{s}^{-1}$, at a constant overpotential to reach a current density of $10 \mathrm{~mA} \cdot \mathrm{cm}^{-2}$ for the OER. The inset shows the chronoamperometric curve of the $\mathrm{FeCO}_{2} \mathrm{O}_{4}$ for the OER at a static potential of $1.4 \mathrm{~V}$ for $20 \mathrm{~h}$.

(Fig. 1(d)). Their OER activities were then compared with those of highly active electrocatalysts recently published in the literature (Table S1). Among them, $\mathrm{FeCo}_{2} \mathrm{O}_{4}$ MMOFs showed an excellent catalytic activity with a current density of $10 \mathrm{~mA} \cdot \mathrm{cm}^{-2}$ at a bias of $1.394 \mathrm{~V}$ (vs. RHE) and a small Tafel slope (61 $\mathrm{mV} \cdot \mathrm{dec}^{-1}$ ) in alkaline media. Figure S4 shows gas chromatography (GC) curves of $\mathrm{FeCo}_{2} \mathrm{O}_{4}$ before and after the OER at the given current density of $10 \mathrm{~mA} \cdot \mathrm{cm}^{-2}$. The GC results clearly confirm that the produced bubbles are $\mathrm{O}_{2}$. The (FE) and the average oxygen production were measured from the samples $\mathrm{ACo}_{2} \mathrm{O}_{4}$ for the OER (Fig. 1(e)). The $98.6 \% \mathrm{FE}$ of $\mathrm{FeCo}_{2} \mathrm{O}_{4}$ confirms that the current is mainly related to water oxidation reaction (Fig. 1(e)). After testing with the continuous cyclic voltammetry characterization for 10,000 cycles at a scanning rate of $100 \mathrm{mV} \cdot \mathrm{s}^{-1}$, the $\mathrm{FeCo}_{2} \mathrm{O}_{4}$ still exhibited a polarization curve with a stable overpotential of $140 \mathrm{mV}$ at $10 \mathrm{~mA} \cdot \mathrm{cm}^{-2}$ (Fig. 1(f)). Fig. 1(f) inset shows that the $\mathrm{FeCo}_{2} \mathrm{O}_{4}$ electrolyzer can retain a current density of $10 \mathrm{~mA} \cdot \mathrm{cm}^{-2}$ over $20 \mathrm{~h}$ of continuous operation without any distinct degradation. After the durability test, the morphology of catalysts was characterized (Fig. S5). The results showed good stability for $20 \mathrm{~h}$. The concentrations of Co and $\mathrm{Fe}$ were detected by inductively coupled plasma mass spectrometry (ICP-MS). The levels of Co and Fe in the solution after the durability test were 0.4 and $0.2 \mu \mathrm{g} \cdot \mathrm{L}^{-1}$, respectively.

Morphology features of the as-obtained $\mathrm{FeCo}_{2} \mathrm{O}_{4}$ were further characterized using SEM. The image of $\mathrm{FeCo}_{2} \mathrm{O}_{4}$ shown in Fig. 2(a) reveals that the sample surface is covered with flower-like particulates (with an average size of $2 \mu \mathrm{m}$ ) formed by dozens of nanoplates with an average thickness of around 60 $\mathrm{nm}$. Energy-dispersive X-ray spectroscopy (EDX) mapping analysis (Fig. 2(b)) reveals that iron, cobalt, and oxygen elements are homogeneously distributed in the $\mathrm{FeCo}_{2} \mathrm{O}_{4}$ sample with the molar ratio of oxygen (46.92 at\%), iron (14.49 at\%), cobalt (29.31 at\%), and carbon (9.27 at\%). The Fe/Co ratio is determined to be $1 / 2$ (inset of Fig. 2(a)).

Further analysis of these nanoplate structures using TEM reveals that they are mesoporous structures (Fig. 2(c)) composed of nanoparticles with an average size of about $12 \mathrm{~nm}$ (Fig. 2(d)). Fig. 2(d) displays a representative HRTEM image of the $\mathrm{FeCo}_{2} \mathrm{O}_{4}$ nanoparticles. The lattice parameter indicated by the arrows in Fig. 2(d) was measured to be $0.22 \mathrm{~nm}$, corresponding to the (311) crystal plane of $\mathrm{FeCo}_{2} \mathrm{O}_{4}$. The nanoplates were further characterized using the selective area electron diffraction (SAED). The four marked diffraction rings in Fig. 2(e) correspond to the (220), (311), (511), and (440) planes of $\mathrm{FeCO}_{2} \mathrm{O}_{4}$.

The porosity of the $\mathrm{FeCo}_{2} \mathrm{O}_{4}$ nanoplates can be determined by $\mathrm{N}_{2}$ sorption analysis (Fig. 2(f)-(g)). The sample exhibits a typical IV type isotherm with a type H3 hysteresis loop, which confirms that this material has a mesoporous structure with an average pore diameter of $17.4 \mathrm{~nm}$. The BET surface area was around $42 \mathrm{~m}^{2} \cdot \mathrm{g}^{-1}$.

Surface chemical composition and element oxidation states of the $\mathrm{FeCo}_{2} \mathrm{O}_{4}$ MMOFs were analyzed using XPS. Fig. 3(a) displays the $\mathrm{C} 1 s$ spectrum of $\mathrm{FeCo}_{2} \mathrm{O}_{4}$ MMOFs. The peaks at 288.4 and $286 \mathrm{eV}$ are assigned to the $\mathrm{O}-\mathrm{C}=\mathrm{O}$ and $\mathrm{C}-\mathrm{O}-\mathrm{C}$ from the pure 

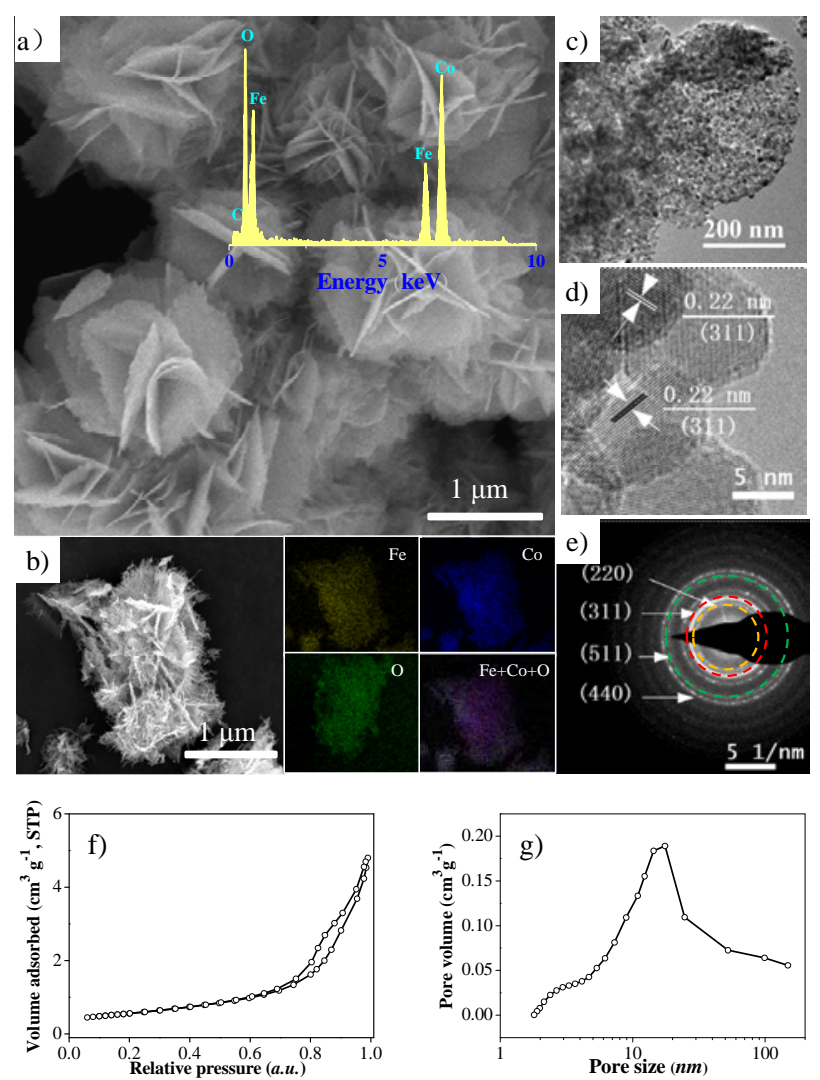

Fig. 2. (a) FESEM images of $\mathrm{FeCo}_{2} \mathrm{O}_{4}$, the inset shows EDX analysis; (b) Element mapping images of $\mathrm{FeCo}_{2} \mathrm{O}_{4}$ for $\mathrm{Fe}, \mathrm{Co}, \mathrm{O}$, and the RGB images composed of three elemental maps; (c) Transmission electron microscopy (TEM) images; (d) HR-TEM image and the corresponding SAED patterns of $\mathrm{FeCo}_{2} \mathrm{O}_{4} ; \mathrm{N}_{2}$ adsorption-desorption isotherms (f) and the pore size distribution (g) of $\mathrm{FeCo}_{2} \mathrm{O}_{4}$, respectively.

PTCDA cyclic anhydride, whereas the peak at $284.4 \mathrm{eV}$ is assigned to the $\mathrm{C}-\mathrm{C}$. Figure $3(\mathrm{~b})$ shows the $01 \mathrm{~s}$ spectrum of
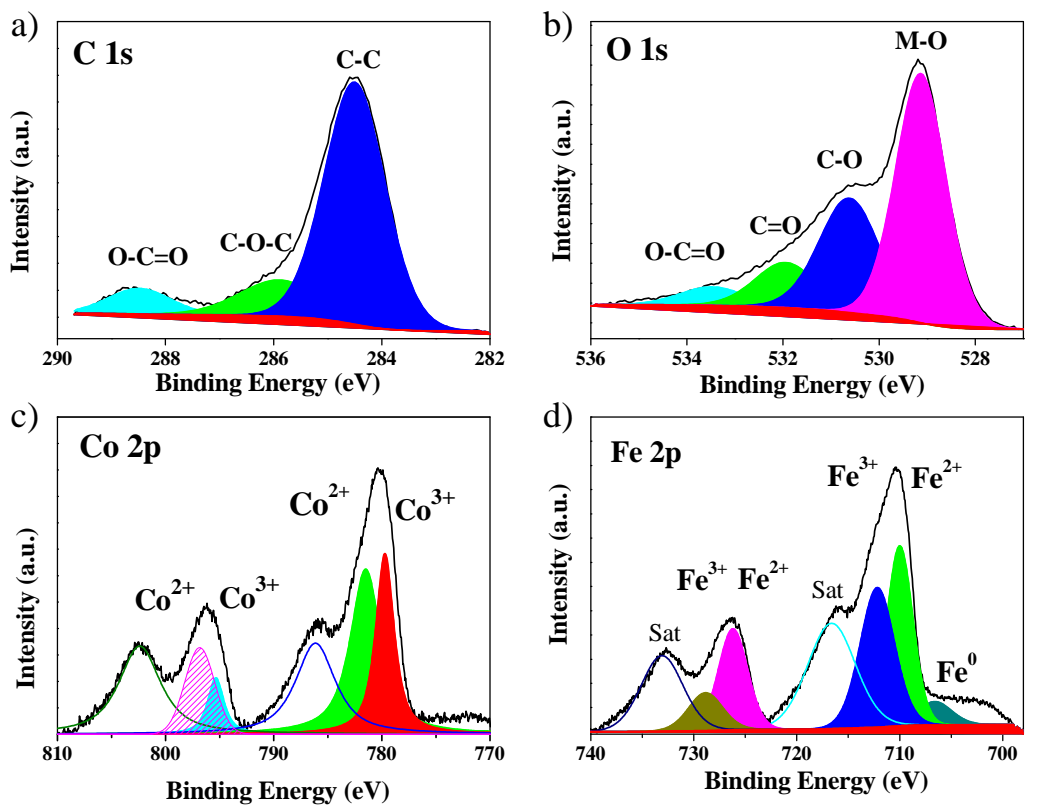

Fig. 3. XPS analysis of $\mathrm{FeCo}_{2} \mathrm{O}_{4}$ MMOFs. (a) C $1 s$; (b) $\mathrm{O} 1 s$; (c) Co $2 p$; (d) Fe $2 p$.

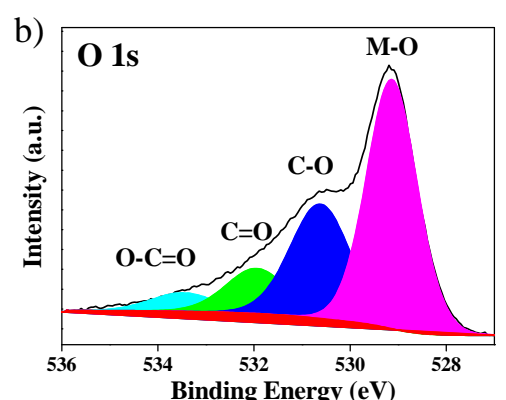

$\mathrm{FeCo}_{2} \mathrm{O}_{4}$ MMOFs. The peaks at 533.6, 532, and $530.5 \mathrm{eV}$ are assigned to the $\mathrm{O}-\mathrm{C}=\mathrm{O}, \mathrm{C}=\mathrm{O}$, and $\mathrm{C}-\mathrm{O}$ from the PTCDA cyclic anhydride, whereas the peak at $529.1 \mathrm{eV}$ is assigned to the $\mathrm{M}-\mathrm{O}$ (where $\mathrm{M}$ represents the metal). In the Co $2 p$ spectra (Fig. 3(c)), two types of $\mathrm{Co}$ species $\left(\mathrm{Co}^{2+}\right.$ and $\left.\mathrm{Co}^{3+}\right)$ are obtained. The binding energies at 782.1 and $797.5 \mathrm{eV}$ are ascribed to $\mathrm{Co}^{2+}$. Another two fitting peaks at 780.1 and $795.4 \mathrm{eV}$ are ascribed to $\mathrm{Co}^{3+}$. These results indicate the co-existence of the Co(II) and $\mathrm{Co}(\mathrm{III})$ in $\mathrm{FeCo}_{2} \mathrm{O}_{4}$ (e.g., $\mathrm{Co}^{3+} / \mathrm{Co}^{2+}$ ratio $=2.0$, estimated from the ratio between the corresponding peak areas). In the Fe $2 p$ spectra (Fig. 3(d)), three types of $\mathrm{Fe}$ species $\left(\mathrm{Fe}^{0}, \mathrm{Fe}^{2+}\right.$, and $\left.\mathrm{Fe}^{3+}\right)$ are detected. The fitted peak at $706.3 \mathrm{eV}$ is ascribed to $\mathrm{Fe}^{0}$, the fitted peaks at 709.9 and $726.0 \mathrm{eV}$ are ascribed to $\mathrm{Fe}^{2+}$, and the fitted peaks at 712.3 and $728.7 \mathrm{eV}$ are ascribed to $\mathrm{Fe}^{3+}$. These results indicate that the iron in $\mathrm{FeCo}_{2} \mathrm{O}_{4}$ has mixed valences $\left(\mathrm{Fe}^{0} / \mathrm{Fe}^{2+} / \mathrm{Fe}^{3+}{ }_{\text {ratio }}=1 / 15 / 10\right.$, estimated from the corresponding peaks areas). The valence values are identified to change from single to mixed for Fe and Co ions.

When the Fe cations hop through the tetrahedral-trigonaloctahedral paths, the numbers of Fe cations increase, and thus a Bader charge of +1.92 e changes into charges of +2.82 e and +2.83 e at the trigonal transition state (TS) and the tetrahedral saddle-point state (SS), respectively. This suggests that the valence state of Fe increases when the Fe cation diffuses from the octahedron to the tetrahedron position. The Co cations also diffuse by moving through the octahedral-trigonal-tetrahedral path as described above but with an activation energy of $1.3 \mathrm{eV}$ and formation energy into a tetrahedral intermediate of $1.2 \mathrm{eV}$. The Bader charge of Co changes from +2.92 e to +1.82 e and +1.83 e at the TS and SS states, respectively. This indicates that the valence state of Co is reduced when the Co cation diffuses from the octahedron to the tetrahedron position. The valence values of Fe and Co, which are obtained from the DFT analysis, are consistent with the XPS results (Fig. 3(c) and 3(d)).

Figure 4(a) illustrates the diffusing paths of metal ions from 
a)

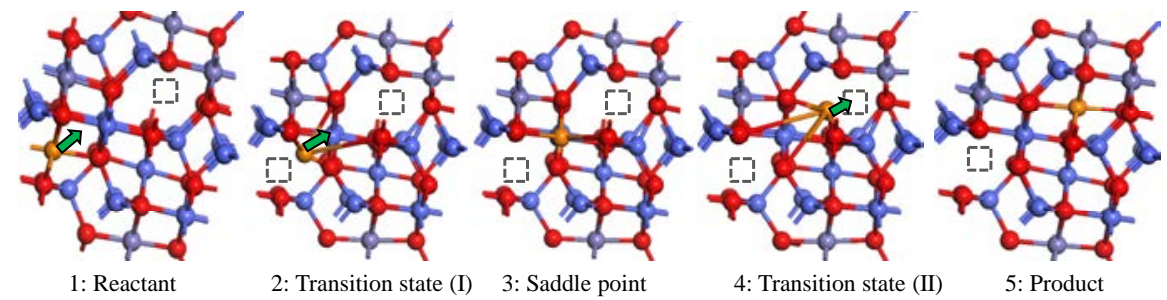

Reaction coordinate
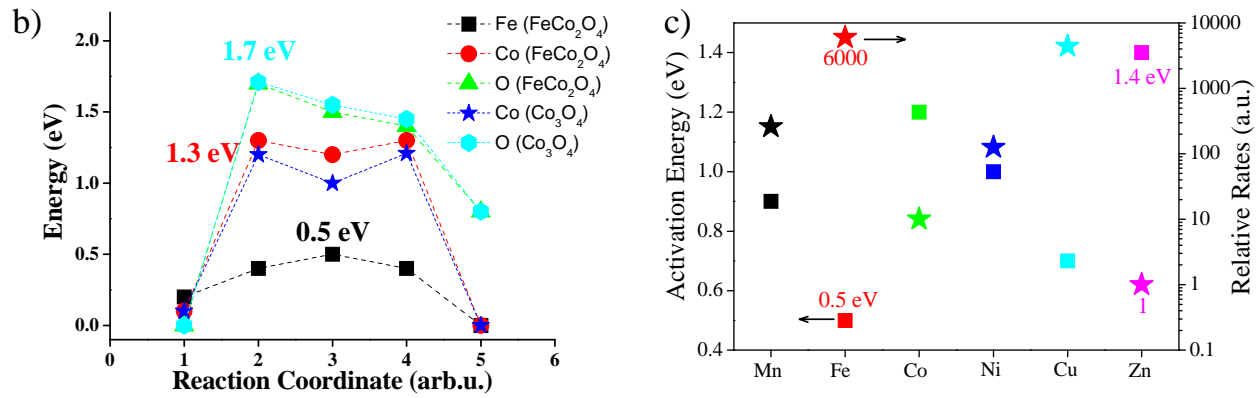

Fig. 4. (a) Geometries of a migrating cation at unique positions along the reaction path. The five representative figures show the initial position of the cation in the octahedral site (1), the cation in the trigonal transition state (I) geometry (2), the cation in the tetrahedral saddle-point geometry (3), the cation in the trigonal transition state (II) geometry (4) and the final position of the cation in the octahedral site (5). The reaction coordinate labels correspond with those of the diffusion potential energy plot. Color scheme: gold sphere for migrating cation, blue for Co, gray for Fe, and red for $\mathrm{O}$. The dotted squares and green arrows indicate cationic vacancies and the direction of the migrating cation along the reaction path, respectively. (b) Hopping activation energies for octahedral-octahedral migration for $\mathrm{Fe}$, Co, and $\mathrm{O}$ ions in $\mathrm{FeCo}_{2} \mathrm{O}_{4}$ and $\mathrm{Co}$ ion in $\mathrm{Co}_{3} \mathrm{O}_{4}$; (c) Activation energies and relative rates for cations $\left(\mathrm{A}=\mathrm{Mn}, \mathrm{Fe}, \mathrm{Co}, \mathrm{Ni}, \mathrm{Cu}\right.$, and $\mathrm{Zn}$ ) hopping in $\mathrm{ACo}_{2} \mathrm{O}_{4}$

the initial octahedral sites to the neighboring octahedral vacancies via a saddle-point plane. As shown in Fig. 4(b), the obtained hopping activation energies of $\mathrm{Fe}$, Co, and $\mathrm{O}$ diffusions are $0.5,1.3$, and $1.7 \mathrm{eV}$, respectively. The obtained hopping activation energies of cationic ( $\mathrm{Fe}$ and $\mathrm{Co}$ ) diffusion for octahedral-octahedral migrations are lower than those of anionic (oxygen) diffusion. This can be attributed to the considerably higher equilibrium concentration of cation vacancies than those of oxygen vacancies in the $\mathrm{ACo}_{2} \mathrm{O}_{4}$ under the OER conditions. Recent studies proved that the crucial step for the OER was the cation diffusion in the spinel catalysts $[12,32,33]$.

The conductivity of catalysts is linked closely with the hopping activation energies, which govern the hopping rate of ion diffusion $[12,34,35]$. We used DFT-based atomistic modeling to calculate the hopping activation energies of ion diffusion processes. Fig. 4(c) depicts the obtained hopping energies for A (A $=\mathrm{Mn}, \mathrm{Fe}, \mathrm{Co}, \mathrm{Ni}, \mathrm{Cu}$, and $\mathrm{Zn}$ ) ions in $\mathrm{ACo}_{2} \mathrm{O}_{4}$ crystals at $25^{\circ} \mathrm{C}$. The hopping activation barrier energies of $\mathrm{Fe}(0.5 \mathrm{eV})$ are much smaller than those of $\mathrm{Cu}(0.7 \mathrm{eV}), \mathrm{Mn}(0.8 \mathrm{eV}), \mathrm{Ni}(1.0 \mathrm{eV})$, Co $(0.95 \mathrm{eV})$, and $\mathrm{Zn}(1.4 \mathrm{eV})$ in $\mathrm{ACo}_{2} \mathrm{O}_{4}$. Based on the ratios of the Arrhenius equations for the various migrations and their associated activation energies [12], the relative rates of cationic hopping through the $\mathrm{ACo}_{2} \mathrm{O}_{4}$ spinels were calculated, and the results are shown in Fig. 4(c). Clearly, the order sequence of the relative rates is as follows: $\mathrm{FeCo}_{2} \mathrm{O}_{4}>\mathrm{CuCo}_{2} \mathrm{O}_{4}>\mathrm{MnCo}_{2} \mathrm{O}_{4}>$ $\mathrm{Co}_{3} \mathrm{O}_{4}>\mathrm{NiCo}_{2} \mathrm{O}_{4}>\mathrm{ZnCo}_{2} \mathrm{O}_{4}$.

Electrical impedance spectroscopy (EIS) characterization (in Fig. S6) was further performed to study the effect of substitution of $\mathrm{A}$ on the electrical resistance of the $\mathrm{ACo}_{2} \mathrm{O}_{4}$ electrodes. The charge transfer between the catalyst and electrolyte was an important indicator for evaluating the catalytic properties. EIS was utilized to analyze the behavior of charge transfer at the interface or the surface. Huge difference in the charge-transfer resistance $\left(R_{\text {in }}\right)$ was observed for these $\mathrm{ACo}_{2} \mathrm{O}_{4}$ electrodes, ranging from the lowest value of $\mathrm{FeCo}_{2} \mathrm{O}_{4}(12.9$ $\left.\Omega \cdot \mathrm{cm}^{-2}\right)$ to the highest value of $\mathrm{ZnCo}_{2} \mathrm{O}_{4}\left(992 \Omega \cdot \mathrm{cm}^{-2}\right)$. Therefore, the high electrical conductivity and faster charge transport of the $\mathrm{FeCo}_{2} \mathrm{O}_{4}$ as an electrode can guarantee its excellent OER performance [36].

When the A-site element is substituted with the transition metal elements $\mathrm{Mn}, \mathrm{Fe}, \mathrm{Co}, \mathrm{Ni}, \mathrm{Cu}$, to $\mathrm{Zn}$ in a sequence, the electron numbers of the corresponding outer d-orbitals change from 5 to 10. The ions of metal elements existed in the form of $\mathrm{Zn}^{2+}, \mathrm{Mn}^{2+}$, and $\mathrm{Cu}^{+}$, whereas the elements $\mathrm{Ni}, \mathrm{Co}$, and $\mathrm{Fe}$ exhibited various oxidation states based on the XPS results (Fig. 5). According to the crystal field (CF) theory [37], the preference of an element to be in octahedral or tetrahedral geometry is mainly determined by the octahedral site preference energy (OSPE), which is defined as the difference between the crystal field splitting energy (CFSE) of the octahedral complex and a tetrahedral complex. To compare the preferences of forming an octahedral field or tetrahedral field, the OSPE can be written as: OSPE $=\operatorname{CFSE}($ oct $)-\operatorname{CFSE}($ tet $)$

From Equation 4, the OSPE value as a function of the number of d-electrons can be calculated. The order of OSPE values for all the cations can be ranked as follows: $\mathrm{Ni}^{2+}>\mathrm{Fe}^{2+}>\mathrm{Co}^{3+}>$ $\mathrm{Co}^{2+}>\mathrm{Fe}^{3+}>\mathrm{Mn}^{2+}>\mathrm{Cu}^{2+}>\mathrm{Zn}^{2+}$.

The elements $\mathrm{Mn}^{2+}, \mathrm{Cu}^{+}$, and $\mathrm{Zn}^{2+}$ preferably occupy a tetrahedral position, but the elements of $\mathrm{Ni}^{2+}$ and $\mathrm{Fe}^{2+}$ prefer an octahedral position. The OSPE values of $\mathrm{Ni}^{2+}$ and $\mathrm{Fe}^{2+}$ are larger 
a)

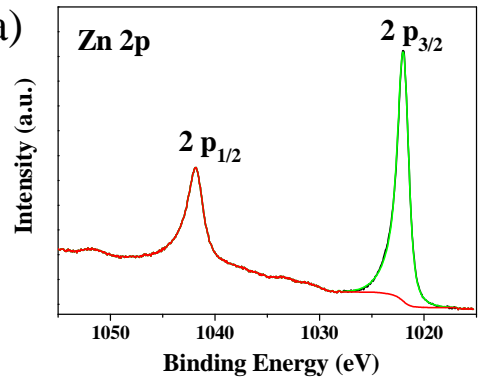

d)

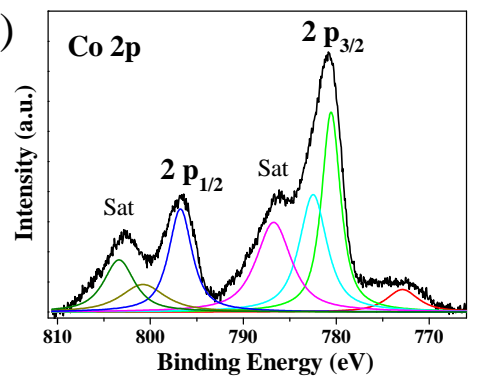

b)

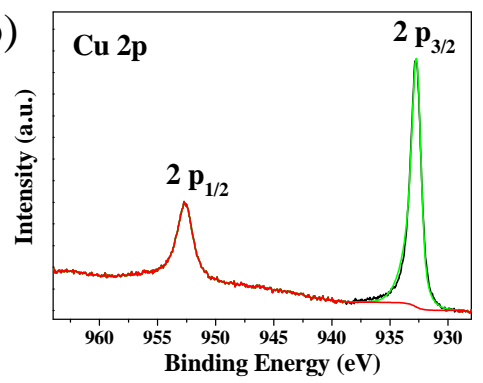

e)

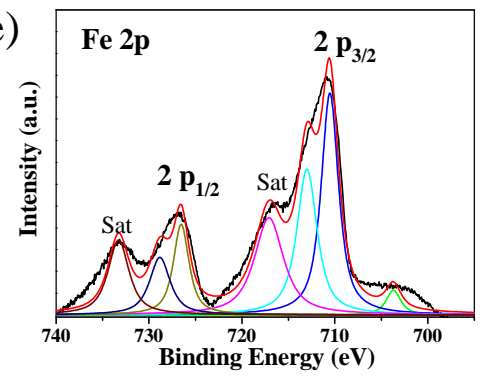

c)

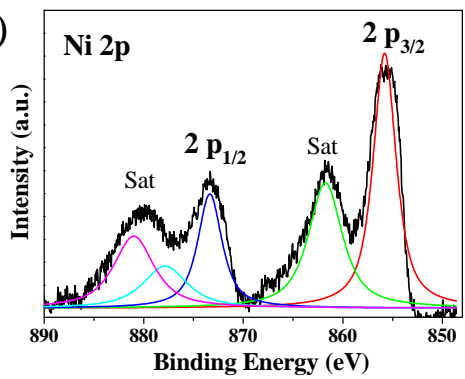

f)

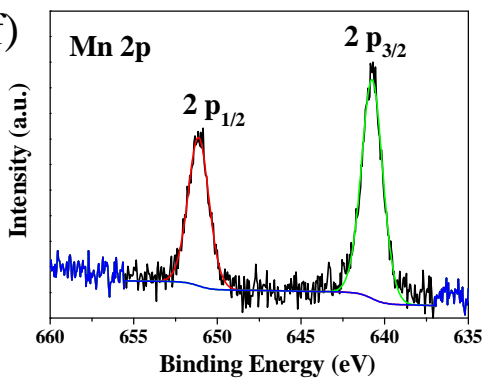

Fig. 5. XPS analysis for $\mathrm{Zn} 2 p$ in $\mathrm{ZnCo}_{2} \mathrm{O}_{4}$ (a), $\mathrm{Cu} 2 p$ in $\mathrm{CuCo}_{2} \mathrm{O}_{4}$ (b), $\mathrm{Ni} 2 p$ in $\mathrm{NiCo}_{2} \mathrm{O}_{4}$ (c), $\mathrm{Co}_{2} p$ in $\mathrm{Co}_{3} \mathrm{O}_{4}(\mathrm{~d}), \mathrm{Fe}_{2} 2 p$ in $\mathrm{FeCo}_{2} \mathrm{O}_{4}$ (e), and $\mathrm{Mn}_{2} p$ in $\mathrm{MnCo}_{2} \mathrm{O}_{4}$ (f).

than that of $\mathrm{Co}^{3+}$, so these cations in the tetrahedron can be exchanged with the octahedral $\mathrm{Co}^{3+}$. The cations $\mathrm{A}^{\prime}$ valence state and distribution can be obtained from the state density of $\mathrm{ACo}_{2} \mathrm{O}_{4}$ crystal (Fig. S7) and X-ray absorption spectroscopy (XAS) $[12,17]$. For the $\mathrm{Fe}^{2+}$ ions, the results showed that exchange between $\mathrm{Fe}(\mathrm{Td}) \leftrightarrow \mathrm{Co}(\mathrm{Oh})$ easily occur. Thus, Fe can occupy both octahedron and tetrahedron positions. This might be the reason why the $\mathrm{FeCo}_{2} \mathrm{O}_{4}$ can easily form composite hybrid spinel structures. Our findings are supported by previous reports that the cations $\mathrm{A}^{\prime}$ valence values depend on the occupied positions $[12,14,17]$. As stated above, the dominant factor for the OER performance of electrode materials is the spinel crystal field. According to the crystal field theory, the spinel crystal field was identified as the essential parameter to control cation A valence values and occupied positions.

\section{Conclusions}

In summary, $\mathrm{ACo}_{2} \mathrm{O}_{4}$ phases $(\mathrm{A}=\mathrm{Mn}, \mathrm{Fe}, \mathrm{Co}, \mathrm{Ni}, \mathrm{Cu}$, or $\mathrm{Zn})$ were successfully synthesized in this work. Among these, the $\mathrm{FeCo}_{2} \mathrm{O}_{4}$ spinel oxide showed excellent OER catalytic activities with a current density of $10 \mathrm{~mA} \cdot \mathrm{cm}^{-2}$ at an overpotential of 164 $\mathrm{mV}$ in alkaline media. Based on our experimental results and theoretical analysis, the spinel crystal field is the dominant factor for the OER performance of electrode materials. The spinel crystal field was further identified as the essential parameter for controlling the hopping activation energies, occupied positions, and valence states of cation $\mathrm{A}$.

\section{Acknowledgments}

The authors would like to thank Yan Shen, the Analytical and Testing Center of HUST, and the Center of Mi-
cro-Fabrication and Characterization of WNLO for the measurements.

\section{References}

[1] C. C. L. McCrory, S. Jung, I. M. Ferrer, S. M. Chatman, J. C. Peters, T. F. Jaramillo, J. Am. Chem. Soc., 2015, 137, 4347-4357.

[2] G. Chen, J. Du, X. Wang, X. Shi, Z. Wang, H.-P. Liang, Chin. J. Catal., 2019, 40, 1540-1547.

[3] X. Sun, Chin. J. Catal., 2019, 40, 1405-1407.

[4] J. Li, Q. Zhuang, P. Xu, D. Zhang, L. Wei, D. Yuan, Chin. J. Catal., 2018, 39, 1403-1410.

[5] M. Mahdavi, M. B. Ahmad, M. J. Haron, F. Namvar, B. Nadi, M. Z. A. Rahman, J. Amin, Molecules, 2013, 18, 7533-7548.

[6] M. Liu, A. Jain, Z. Rong, X. Qu, P. Canepa, R. Malik, G. Ceder, K. A. Persson, Energy Environ. Sci., 2016, 9, 3201-3209.

[7] Z. Wang, P. K. Nayak, J. A. Caraveo-Frescas, H. N. Alshareef, Adv. Mater., 2016, 28, 3831-3892.

[8] T. Tatarchuk, M. Bououdina, J. Judith Vijaya, L. John Kennedy, Springer International Publishing, Cham, 2017, 305-325.

[9] R. J. Hill, J. R. Craig, G. V. Gibbs, Phys. Chem. Miner., 1979, 4, 317-339.

[10] Y.-T. Lu, Y.-J. Chien, C.-F. Liu, T.-H. You, C.-C. Hu, J. Mater. Chem. A, 2017, 5, 21016-21026.

[11] C. C. L. McCrory, S. H. Jung, J. C. Peters, T. F. Jaramillo, J. Am. Chem. Soc., 2013, 135, 16977-16987.

[12] C. L. Muhich, V. J. Aston, R. M. Trottier, A. W. Weimer, C. B. Musgrave, Chem. Mater., 2016, 28, 214-226.

[13] F. Cheng, J. Shen, B. Peng, Y. Pan, Z. Tao, J. Chen, Nature Chemistry, 2010, 3, 79.

[14] T. Wang, Y. Sun, Y. Zhou, S. Sun, X. Hu, Y. Dai, S. Xi, Y. Du, Y. Yang, Z. J. Xu, ACS Catal., 2018, 8, 8568-8577.

[15] Yiliguma, Z. Wang, W. Xu, Y. Wang, X. Cui, A. M. Al-Enizi, Y. Tang, G. Zheng, J. Mater. Chem. A, 2017, 5, 7416-7422.

[16] T. H. Lim, S. B. Park, J. M. Kim, D. H. Kim, J. Mol. Catal. A, 2017, 426, 


\title{
Graphical Abstract
}

Chin. J. Catal., 2020, 41: 1855-1863 doi: 10.1016/S1872-2067(20)63638-5

Highly efficient mixed-metal spinel cobaltite electrocatalysts for the oxygen evolution reaction

Leiming Tao, Penghu Guo, Weiling Zhu, Tianle Li, Xiantai Zhou,

Yongqing $\mathrm{Fu}$, Changlin $\mathrm{Yu}$ *, Hongbing Ji *

Guangdong University of Petrochemical Technology, China;

Huazhong University of Science and Technology, China;

Northumbria University, UK; Sun Yat-sen University, China

Cation substitution of spinel cobaltites is a promising strategy for optimizing the electrochemical performance for water splitting. The $\mathrm{FeCO}_{2} \mathrm{O}_{4}$ has an overpotential of $164 \mathrm{mV}$ at a current density of $10 \mathrm{~mA} \cdot \mathrm{cm}^{-2}$ in alkaline media. The underlying mechanisms have been clarified by cation substitution with different numbers of d-electrons between 5 and 10 . The crystal field of spinel $\mathrm{ACo}_{2} \mathrm{O}_{4}$ is identified as the key factor in dictating the OER performance of these spinel cobaltites.

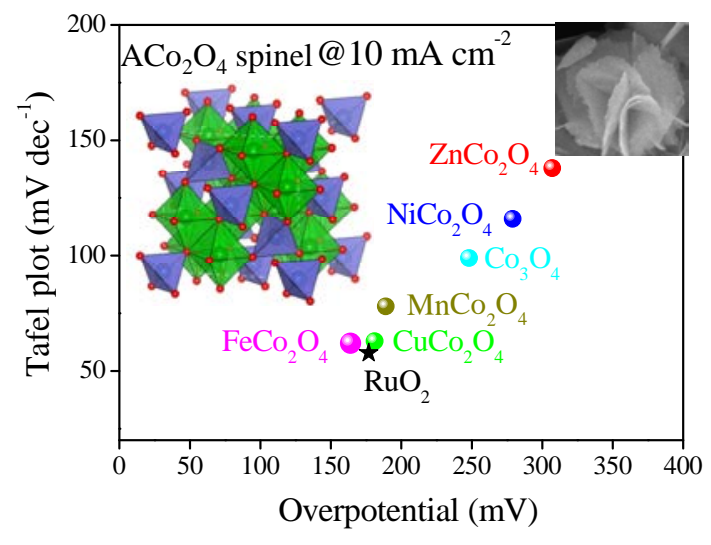

68-74.

[17] C. Wei, Z. X. Feng, G. G. Scherer, J. Barber, Y. Shao-Horn, Z. C. J. Xu, Adv. Mater., 2017, 29, 1606800.

[18] X. Liu, Z. Chang, L. Luo, T. Xu, X. Lei, J. Liu, X. Sun, Chem. Mater., 2014, 26, 1889-1895.

[19] M. Prabu, K. Ketpang, S. Shanmugam, Nanoscale, 2014, 6, 3173-3181.

[20] G. S. Hutchings, Y. Zhang, J. Li, B. T. Yonemoto, X. Zhou, K. Zhu, F. Jiao, J. Am. Chem. Soc., 2015, 137, 4223-4229.

[21] J. Zhao, F. Wang, P. Sun, M. Li, J. Chen, Q. Yang, C. Li, J. Mater. Chem., 2012, 22, 13328-13333.

[22] T. Shinagawa, A. T. Garcia-Esparza, K. Takanabe, Sci. Rep., 2015, 5, 13801.

[23] S. Zhao, Y. Wang, J. Dong, C.-T. He, H. Yin, P. An, K. Zhao, X. Zhang, C. Gao, L. Zhang, J. Lv, J. Wang, J. Zhang, A. M. Khattak, N. A. Khan, Z. Wei, J. Zhang, S. Liu, H. Zhao, Z. Tang, Nature Energy, 2016, 1, 16184.

[24] A. J. Bard, L. R. Faulkner, J. Chem. Educ., 2001, 60, 80-89.

[25] J. P. Singh, R. N. Singh, J. New Mater. Electrochem. Syst., 2000, 3, 137-146.

[26] S. Gao, Y. Lin, X. C. Jiao, Y. F. Sun, Q. Q. Luo, W. H. Zhang, D. Q. Li, J. L.
Yang, Y. Xie, Nature, 2016, 529, 68-+.

[27] B. Iandolo, B. Wickman, B. Seger, I. Chorkendorff, I. Zorić, A. Hellman, Phys. Chem. Chem. Phys., 2014, 16, 1271-1275.

[28] G. Kresse, J. Furthmüller, Phys. Rev. B, 1996, 54, 11169-11186.

[29] G. Kresse, D. Joubert, Phys. Rev. B, 1999, 59, 1758-1775.

[30] J. P. Perdew, K. Burke, M. Ernzerhof, Phys. Rev. Lett., 1996, 77, 3865-3868.

[31] S. L. Dudarev, G. A. Botton, S. Y. Savrasov, C. J. Humphreys, A. P. Sutton, Phys. Rev. B, 1998, 57, 1505-1509.

[32] F. Li, Z. Sun, S. Luo, L.-S. Fan, Energy Environ. Sci., 2011, 4, 876-880.

[33] L. Yuan, Y. Wang, R. Cai, Q. Jiang, J. Wang, B. Li, A. Sharma, G. Zhou, Mater. Sci. Eng., 2012, 177, 327-336.

[34] R. Pornprasertsuk, P. Ramanarayanan, C. B. Musgrave, F. B. Prinz, J. Appl. Phys., 2005, 98, 103513.

[35] M. Asnavandi, Y. Yin, Y. Li, C. Sun, C. Zhao, ACS Energy Lett., 2018, 3, 1515-1520.

[36] K. Liang, L. Guo, K. Marcus, S. Zhang, Z. Yang, D. E. Perea, L. Zhou, Y. Du, Y. Yang, ACS Catal., 2017, 7, 8406-8412.

[37] R. G. Burns, Mineralogical Applications of Crystal Field Theory, Cambridge University Press, 1993.

\section{基于尖晶石型混合金属钴矿的高效析氧电催化性能}

\author{
陶䂞明 ${ }^{\mathrm{a}, \mathrm{b}}$, 郭鹏虎 $\mathrm{a}$, 朱伟玲 ${ }^{\mathrm{a}}$, 李天乐 ${ }^{\mathrm{a}}$, 周贤太 ${ }^{\mathrm{d}}$, 傅永庆 ${ }^{\mathrm{c}}$, 余长林 ${ }^{\mathrm{a}, \#}$, 纪红兵 ${ }^{\mathrm{a}, \mathrm{d},{ }^{*}}$ \\ $\mathrm{a} 广$ 东石油化工学院理学院, 广东茂名 525000 , 中国 \\ 华中科技大学武汉光电国家研究中心, 湖北武汉430074, 中国 \\ c 诺森比亚大学工程与环境学院, 纽卡斯尔, 英国 \\ d 中山大学化学学院, 精细化工研究院, 广东广州510275, 中国
}

摘要: 尖晶石钴矿 (例如 $\mathrm{ACo}_{2} \mathrm{O}_{4}$, 其中 $\mathrm{A}=\mathrm{Mn}, \mathrm{Fe}, \mathrm{Co}, \mathrm{Ni}, \mathrm{Cu}$ 或 Zn的阳离子取代)是一种精确调控其电子结构/性质, 并因此 改善相应的电催化水分解析氧(OER)性能的有前途的策略. 然而, 有关它的基本原理和机制尚未完全理解. 为了确定尖晶 石氧化物在OER中的作用, 已有实验和理论报道. 例如, Prabu发现 $\mathrm{Ni}^{3+}$ 离子取代 $\mathrm{NiCo}_{2} \mathrm{O}_{4}$ 的八面体位点可以显着提高OER 性能; Hutchings报道OER性能提高源自 $\mathrm{Co}_{3} \mathrm{O}_{4}$ 八面体 $\mathrm{Co}^{3+}$ 的活性位; Wei研究发现 $\mathrm{MnCo}_{2} \mathrm{O}_{4}$ 八面体位置的 $\mathrm{Mn}^{3+}$ 离子是OER 
的活性位点. 尽管多数研究没有对此给出清晰的解释, 但这些研究清楚地表明, 尖晶石氧化物对OER的电催化性能在很大 程度上取决于过渡金属阳离子(A)的化合价态及其在尖晶石结构中的相应位点分布. 本文旨在合成具有同种形貌的尖晶石 $\mathrm{ACo}_{2} \mathrm{O}_{4}$ 混合金属有机骨架(MMOFs)材料, 通过 $\mathrm{A}$ 位引入外层 $d$ 电子数从 5 到 10 的过渡金属元素, 如 $\mathrm{Mn}, \mathrm{Fe}, \mathrm{Co}, \mathrm{Ni}, \mathrm{Cu}$ 和 $\mathrm{Zn}$, 系统研究催化水分解析氧机理. 基于实验详细分析了不同阳离子的取代和其OER的催化行为, 在获得的六种尖晶石 $\mathrm{ACo}_{2} \mathrm{O}_{4}$ 催化剂中, $\mathrm{FeCo}_{2} \mathrm{O}_{4}$ 催化剂在碱性溶液中具有出色的OER性能和稳定性, 其在电流密度 $10 \mathrm{~mA} \cdot \mathrm{cm}^{-2}$ 的超电势下 164 $\mathrm{mV}$. 催化剂的电荷传输性能与离子和空位扩散的跳跃率密切相关. 我们使用密度泛函理论计算阳离子在 $\mathrm{ACo}_{2} \mathrm{O}_{4}$ 晶体中 的扩散以及扩散的活化能, 并且计算过程考虑自旋的激发能. 使用VASP的搜索过渡态方法(NEB-DMTS)确定离子扩散的 最小能量反应路径. 结果表明, 尖晶石钴矿 $\mathrm{ACo}_{2} \mathrm{O}_{4}$ 晶格中的 $\mathrm{Fe}$ 取代可以显著加速电荷转移, 从而获得增强的电化学性能. 由第一性原理计算Fe阳离子通过四面体-三角平面-八面体路径扩散, 具有 $0.4 \mathrm{eV}$ 的活化能和 $0.5 \mathrm{eV}$ 的能量以形成八面体中 间体. 当它跳跃时, 阳离子 $(\mathrm{Fe})$ 分别在过渡态和四面体鞍点(亚稳态)下从 +1.82 的Bader电荷增加到 +2.82 和 +2.83 的电荷, 这 表明扩散的Fe在不同的位置具有的相应的价态. 根据晶体场理论, 通过八面体位置偏好能量(OSPE)是用于判断阳离子占 据八面体或四面体的位置, 其被定义为占据八面体和四面体的晶体场能量(CFSE)差. OSPE的顺序依次是 $\mathrm{Ni}^{2+}>\mathrm{Ni}^{3+}>$ $\mathrm{Mn}^{3+}>\mathrm{Fe}^{2+}>\mathrm{Co}^{3+}>\mathrm{Co}^{2+}>\mathrm{Fe}^{3+}>\mathrm{Mn}^{2+}>\mathrm{Cu}^{2+}>\mathrm{Zn}^{2}$, 由于Fe(II)、Co(II)和Ni(II)的OSPE值大于 $\mathrm{Co}(\mathrm{III})$ 的OSPE值, 这三种阳离子 在四面体可以与八面体 $\mathrm{Co}(\mathrm{III})$ 发生交换. 对 $\mathrm{Fe}(\mathrm{II})$ 离子, 研究发现 $\mathrm{Fe}(\mathrm{Td}) \leftrightarrow \mathrm{Co}(\mathrm{Oh})$ 交换很容易进行, Fe既可以占据八面体又 可以占据四面体, 所以 $\mathrm{FeCo}_{2} \mathrm{O}_{4}$ 为复合尖晶石结构, 可以从 $\mathrm{ACo}_{2} \mathrm{O}_{4}$ 晶体的 $\mathrm{X}$ 射线吸收光谱法获得阳离子 $\mathrm{A}$ 的价态和分布证 实. 更深入研究发现尖晶石 $\mathrm{ACo}_{2} \mathrm{O}_{4}$ 的晶体场, 不仅决定A位阳离子的价态, 同时影响这些尖晶石钴矿OER性能的关键因素. 关键词: 阳离子取代的尖晶石钴矿; 晶体场; 氧还原反应; 水分解; 电催化

收稿日期: 2020-03-11. 接受日期: 2020-04-14. 出版日期: 2020-12-05.

*通讯联系人. 电话/传真: (0668)2923081; 电子信箱: jihb@mail.sysu.edu.cn

\#通讯联系人. 电子信箱: yuchanglinjx@163.com

基金来源：国家自然科学基金(21938001, 21576302, 21878344 和201961160741); 国家自然科学基金委-中国石化股份公司石油化 工联合基金 (U1663220); 广东省重点研发计划 (2019B110206002); 广东省教育厅特色创新项目 (2018KTSCX144, 2016KTSCX087); 广东珠江人才计划地方创新研究团队项目(2017BT01C102); 广东省高校珠江学者计划(2019); 广东普通高校 重点项目<自然>(2019KZDXM010); 广东省基础与应用基础研究基金(2019A1515011249); 广东石油化工学院自然科学基金科研 基金(2019rc019, 2019rc053); 英国工程与物理科学研究委员会(EPSRC)提供资助(EP/P018998/1); 英国皇家学会和中国国家自然 科学基金委员会的牛顿交流基金(IE161019).

本文的电子版全文由Elsevier出版社在ScienceDirect上出版(http://www.sciencedirect.com/science/journal/18722067). 